\title{
Workshop Dan Pendampingan Pembuatan Game Edukasi Berbasis Android Bagi Guru SDN 2 Cakranegara
}

\author{
Muhammad Makki', Dyah Indraswati², Muhammad Erfan ${ }^{3}$, Aisa Nikmah Rahmatih", Vivi Rachmatul \\ Hidayati*5 \\ 1,2,3,4,5 Program Studi Pendidikan Guru Sekolah Dasar, FKIP, Universitas Mataram \\ *e-mail: muhammadmakki12@yahoo.co.id ${ }^{1}$, dyahindraswati@unram.ac.id ${ }^{2}$, muhammaderfan@unram.ac.id ${ }^{3}$, \\ aisanikmahrahma07@unram.ac.id ${ }^{4}$, vivirachma@unram.ac.id ${ }^{* 5}$
}

\begin{abstract}
The Covid-19 pandemic has led to policies that make teachers and students have to adapt the face-toface learning model to online learning. The teacher of SD N 2 Cakranegara admits that there are limitations to the variety of audio-visual learning media used. The teachers also don't know and have never tried to develop game games with learning content, even though Android-based games are very possible to be developed and accessed portable on smartphones, the majority of which are already owned by teachers and students. The provision of workshops and assistance in making Android-based educational games for SD N 2 Cakranegara teachers aims to improve skills in creating and developing learning media in the form of educational games and maximizing the use of smartphones. The targeted output in this service activity is the existence of educational games that are ready to be used for the online learning process through appsgeyser.com and quickappninja.com.
\end{abstract}

Keywords: workshop; development; game; android

\begin{abstract}
Abstrak
Pandemi Covid-19 menyebabkan adanya kebijakan yang membuat guru dan siswa harus menyesuaikan model pembelajaran tatap muka dengan pembelajaran daring. Guru SD N 2 Cakranegara mengakui adanya keterbatasan variasi media pembelajaran audio visual yang dipergunakan. Para guru juga tidak tahu dan belum pernah mencoba mengembangkan permainan game dengan konten pembelajaran, padahal game berbasis android sangat memungkinkan dikembangkan dan diakses secara portable di smartphone yang mayoritas sudah dimiliki guru dan siswa. Pengadaan workshop dan pendampingan pembuatan game edukasi berbasis Android bagi Guru SD N 2 Cakranegara bertujuan meningkatkan keterampilan (skill) dalam membuat dan mengembangkan media pembelajaran dalam bentuk game edukasi dan memaksimalkan penggunaan smartphone. Adapun luaran yang ditargetkan dalam kegiatan pengabdian ini adalah adanya game edukasi yang siap digunakan untuk proses pembelajaran daring melalui melalui appsgeyser.com dan quickappninja.com.
\end{abstract}

Kata kunci: workshop; pengembangan; game; android

\section{PENDAHULUAN}

Pandemi COVID-19 menyebabkan terjadinya perubahan pada berbagai macam sendi kehidupan baik social, pariwisata, ekonomi, kesehatan, maupun pendidikan. Dalam bidang pendidikan, Menteri Pendidikan dan Kebudayan Republik Indonesia menerbitkan Surta Edaran Nomor 4 Tahun 2020 Tentang Pelaksanaan Kebijakan Pendidikan Dalam Masa Darurat penyebaran Covid. Hal ini menyebabkan terjadinya pemberlakuan pembelajaran daring (dalam jaringan/online) sebagai pengganti dari pembelajaran tatap muka (luring) (Dewi, 2020). Guru dan siswa harus menyesuaikan model pembelajaran tatap muka yang selama ini diterapkan dengan pembelajaran daring.

Pembelajaran daring bertumpu pada penggunaan berbagai macam platform media pembelajaran seperti webmeeting, google classroom, WhatsApp, dan sebagainya. Berdasarkan hasil wawancara dengan guru kelas SDN 2 Cakranegara, kegiatan belajar mengajar lebih banyak menggunakan WhatsApp Group dan sesekali menggunakan Google Meet yang terintegrasi dengan Platform Google Classroom. Meskipun begitu, kegiatan belajar secara luring juga dilakukan beberapa hari dalam satu minggu yang dikhususkan bagi siswa kelas tinggi. Permasalahan yang 
terjadi selama pembelajaran daring yang dilakukan di SDN 2 Cakranegara meliputi fasilitas peserta didik yang masih kurang, kuota paket data yang tidak mencukupi, tidak adanya pendamping kegiatan belajar di rumah, siswa cenderung merasa bosan apabila terlalu lama menggunakan webmeeting.

Salah satu metode pembelajaran daring yang dapat dilakukan dengan tetap memotivasi siswa untuk tetap belajar dan memiliki rasa kaingintahuan yang tinggi adalah dengan memanfaatkan game edukasi. Game edukasi adalah bentuk permainan yang dirancang untuk memberikan pendidikan atau pembelajaran bagi pemainnya (Ariona, 2014). Siswa juga dapat bermain game secara online dengan menggunakan smartphone.

Berbagai hasil penelitian mengenai dampak positif game diantaranya adalah Video game dapat meningkatkan motivasi dan konsentrasi siswa (P \& D, 2014), bermain game juga dapat meningkatkan kreativitas pemain (Blanco-Herrera, Gentile, \& Rokkum, 2019), permainan tertentu dapat meningkatkan hasil belajar siswa (Dewantara, Wati, Misbah, Mahtari, \& Haryandi, 2020), selain itu bermain game juga dapat meningkatkan kemampuan pemecahan masalah bagi siswa (Granic, Lobel, \& Engels, 2014). Permainan game tertentu juga dapat digunakan sebagai alat evaluasi hasil belajar siswa (Dewi, Sholikhah, Ghofur, \& Soejoto, 2020).

Game juga membawa dampak negative antara lain menyebabkan control emosi yang tidak stabil pada siswa (Quwaider, Alabed, \& Duwairi, 2019), gangguan penglihatan atau visual dan juga dapat menyebabkan kegemukan karena kurangnya aktivitas fisik (Ayenigbara, 2018), menyebabkan kecanduan apabila terlalu banyak bermain game (Grüsser, Thalemann, \& Griffiths, 2007). Dalam upaya mengintegrasikan konten pembelajaran ke dalam permainan game yang berbasis android, guru harus senantiasa memperhatikan dampak positif dan negative dari bermain game yang dimanfaatkan sebagai media pembelajaran.

Berdasarkan hasil wawancara, guru-guru SDN 2 Cakranegara mengakui bahwa pembelajaran daring belum maksimal dikarenakan terbatasnya variasi media pembelajaran audio visual yang dipergunakan. Para guru juga tidak tahu dan belum pernah mencoba mengembangkan permainan game dengan konten pembelajaran, padahal game berbasis android sangat memungkinkan dikembangkan dan diakses secara portable di smartphone yang mayoritas sudah dimiliki guru dan siswa. Pengadaan workshop dan pendampingan pembuatan game edukasi berbasis Android bagi Guru SD N 2 Cakranegara bertujuan meningkatkan keterampilan (skill) dalam membuat dan mengembangkan media pembelajaran dalam bentuk game edukasi dan memaksimalkan penggunaan smartphone. Adapun luaran yang ditargetkan dalam kegiatan pengabdian ini adalah adanya game edukasi yang siap digunakan untuk proses pembelajaran daring.

\section{METODE}

Kegiatan pengabdian dilaksanakan di SD N 2 Cakranegara sebagai upaya menyelesaikan permasalahan yang ada pada mitra. Kegiatan ini dikhususkan untuk melatih guru SD N 2 Cakranegara membuat dan megembangkan game edukasi berbasis Android yang dapat dipasang (install) pada smartphone siswa. Website yang digunakan untuk membuat game Android ini adalah Appgeyser.com dan QuickApp Ninja yang memberikan fasilitas pembuatan game Android secara cuma-cuma (gratis). Jenis game edukasi seperti kuis, memasangkan, tebak gambar, memberikan warna, mencari kata dapat dibuat dan dikembangkan oleh guru tanpa memerlukan kemampuan coding. Guru hanya perlu menyiapkan komponen-komponen game seperti pertanyaan, gambar dan icon, music atau suara yang berbunyi ketika pengguna menjawab kuis dengan benar atau salah serta background music. Guru bisa memberikan penilaian kepada siswa dan kriteria siswa yang menyelesaikan game dengan score tertinggi atau waktu tercepat. 
Konten game edukasi tidak tersedia secara instan dan perlu beberapa software lain dalam pengolahan gambar, icon, background, serta suara. Oleh karena itu, dalam kegiatan workshop dan pendampingan ini ada tutorial penggunaan software pendukung seperti Adobe Photosop, Corel Draw, Canva, serta PixelLab yang bertujuan menghasilkan komponen pendukung game edukasi.

berikut:

Langkah-langkah pelaksanaan kegiatan workshop dan pendampingan adalah sebagai

1. Pemaparan manfaat anak belajar dengan game seperti meningkatkan daya ingat, lebih fasih dalam menggunakan alat digital dan simulasi, melatih kemampuan pemecahan masalah dan strategi, serta mengenal sejarah bisa dilakukan dengan bermain game.

2. Pemaparan game edukasi sederhana yang ternyata mudah dibuat, lebih focus ke konten edukasi, dan memiliki kompatibilitas dan aksesibilitas luas.

3. Pemaparan dan pengenalan website khususnya Appgeyser.com dan QuickApp Ninja yang menyediakan wahana pengembangan game edukasi berbasis Android.

4. Demonstrasi pembuatan beberapa jenis game edukasi seperti game kuis, game tebak gambar, serta permainan mencari kata dan istilah.

5. Praktik langsung melalui kegiatan workshop di mana masing-masing guru mencoba mengembangkan dan membuat game berbasis Android untuk salah satu materi tertentu. Kegiatan praktik langsung yang dilakukan pada proses penyiapan komponen game Android dilakukan secara bertahap mulai dari praktik cara image tracing menggunakan Corel Draw, image resizing (mengubah dimensi gambar) dengan menggunakan Adobe Photoshop, menghilangkan atau mengubah background gambar dengan Adobe Photoshop, membuat icon game dengan Adobe Photoshop, serta pengenalan sistem warna RGB dalam kode hexadesimal.

6. Pertanyaan mengenai cara pembuatan maupun proses pengembangan game edukasi tergabung dalam kegiatan 3 yaitu praktik langsung di mana guru-guru yang menemui kendala dapat langsung mengajukan pertanyaan.

7. Diakhir kegiatan guru-guru juga diberi tahu cara-cara upload Game edukasi ke dalam Play Store.

\section{HASIL DAN PEMBAHASAN}

Kegiatan pengabdian kepada masyarakat ini dilaksanakan di SDN 2 Cakranegara, kota Mataram pada Sabtu, 28 Agustus 2021 pukul 11.00 - 15.00 WITA. Bentuk kegiatan pengabdian ini berupa pelatihan pembuatan games (permainan) edukasi berbasis android. Sasaran kegiatan ini adalah seluruh guru di SDN 2 Cakranegara, kota Mataram. Kegiatan pengabdian ini meliputi pelatihan yang diintegrasikan langsung dengan proses praktik dalam pembuatan game edukasi berbasis android. Terdapat 2 game maker yang diperkenalkan pada peserta pada kegiatan ini, yakni appsgeyser.com dan quickappninja.com.

Kegiatan pengabdian diawali dengan pembukaan oleh MC (Aisah Nikmah Rahmatih, S.Pd., M.Pd.). Setiap anggota pengabdian yang hadir memperkenalkan diri masing-maising. Selanjutnya, sambutan dari ketua tim pengabdian (Dr. Muhammad Makki, M.Pd.) memberikan gambaran umum mengenai sebab dan tujuan dari pelaksanaan pengabdian. Kepala SDN 2 Cakranegara memberikan sambutan serta melaporkan jumlah guru yang dapat mengikuti kegiatan pelatihan ini. Kepala SDN 2 Cakranegara menyatakan bahwa kegiatan pelatihan pembuatan media pembelajaran, utamanya game yang berbabasis gadget seperti ini memang sangat dibutuhkan oleh guru-guru saat ini.

Pemateri pertama (Dyah Indraswati, S.Pd., M.Pd.) menjelaskan mengenai "Mengapa belajar dengan game?". Aktivitas penggunaan smartphone oleh semua orang dari berbagai usia didominasi oleh aktivitas mobile gaming (25\%). Berdasarkan hasil survey, terdapat 50,6\% responden pengguna smartphone bermain game setiap hari dengan durasi pemakaian paling didominasi pada rentang waktu 20-30 menit. Tipe game yang paling banyak diakses oleh mobile 
gamers adalah Puzzle, Arcade, dan Action. Hal ini mengindikasikan bahwa bermain game menjadi salah satu alternatif aktivitas pembelajaran. Hal ini dikarenakan anak-anak akan senang jika belajar sambil bermain dan bermain sambil belajar. Anak-anak juga bisa belajar dari kesalahan.

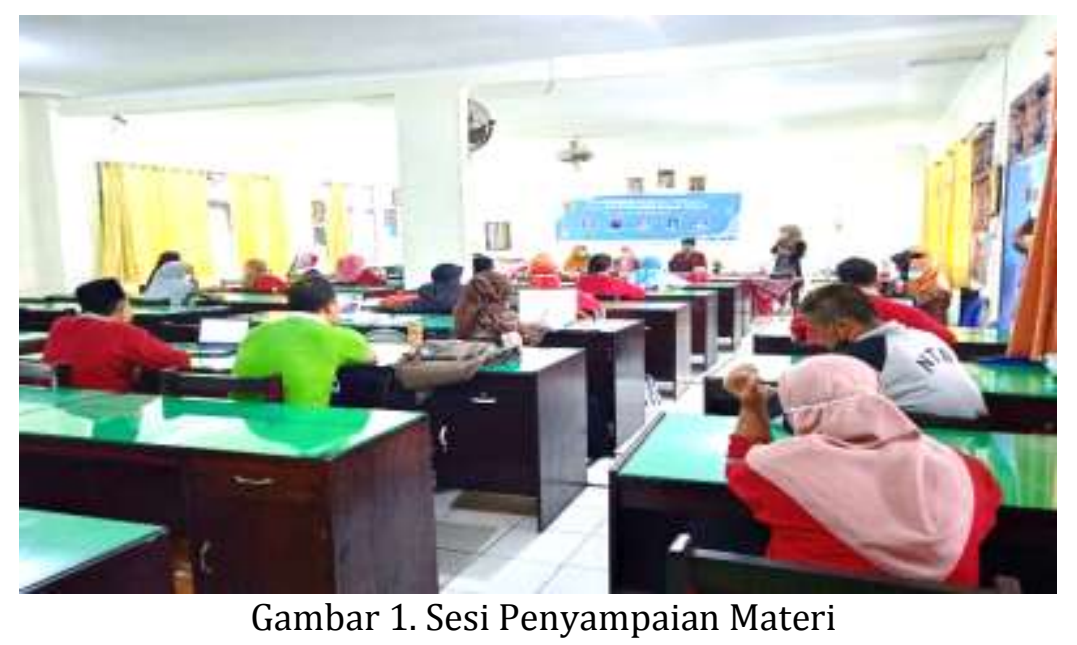

Pemateri kedua (Aisa Nikmah Rahmatih, S.Pd., M.Pd.) menjelaskan manfaat dari bermain game. Manfaat bagi anak bermain game adalah menambah daya ingat mereka. Anak-anak dapat mengingat banyak karakter dan hal yang ada pada game karena mereka menikmati bermain game. Hal ini memungkinkan anak-anak akan mudah mengingat hal-hal yang berkenaan dengan mata pelajaran jika disisipkan game pada pembelajaran. Menfaat selanjutnya adalah anak-anak akan menjadi lebih fasih dalam menggunakan alat digital. Hal ini juga bisa memudahkan guru ketika anak-anak nantinya harus mengoperasikan peralatan-peralatan digital yang dibutuhkan dalam pembelajaran. Manfaat lainnya adalah anak-anak memiliki kemampuan problem solving yang baik. Game edukasi dapat dibuat secara sederhana dan lebih fokus ke konten materi. Beberapa website atau aplikasi dapat dimanfaatkan untuk mebuat game edukasi sederhana, yakni quickappninja.com dan appsgeyser.com.

Pemateri ketiga (Dr. Muhammad Makki, M.Pd.) menjelaskan bagaimana cara membuat game quiz di appsgeyser.com. Peserta menyaksikan pemaparan pemateri sambil praktik secara langsung dengan laptop masinng-masing. Pemateri menjelaskan bahwa ada beberapa jenis game yang dapat dibuat dari website ini, yakni arcade (teka-teki) dan puzzle. Kedua jenis tersebut terdiri dari berbagai game, yang salah satu diantaranya adalah quiz. Game quiz yang dapat dibuat pada website dapat disesuaikan dengan muatan mata pelajaran yang diinginkan. Kita bisa memilih jenis pertanyaan dan gambar yang akan disisipkan pada quiz. Jenis jawaban juga terdiri dari pilihan ganda, benar/salah, dan isian singkat. Creator juga bisa mendesain warna teks, background, dan button (tempat klik).

Pemateri keempat (Vivi Rachmatul Hidayati, S.Pd., M.Pd.) menjelaskan proses selanjutnya dalam membuat game melalui appsgeyser.com. Dikarenakan quiz ini berbasis game android, maka kumpulan pertanyaan bersifat seperti tahap-tahap yang harus dilalui dalam bermain game. Setelah kumpulan pertanyaan dianggap cukup untuk game tersebut, maka langkah selanjutnya adalah membuat game tersebut menjadi aplikasi yang bisa dijalankan di smartphone android. Website ini bisa mengkonversi aplikasi game ke dalam apk berbasis android. Setelah aplikasi sudah didownload dan diinstal ke dalam smartphone yang berbasis android, maka game tersebut dapat dimainkan dengan sangat mudah. Ada beberapa peserta yang mampu membuat quiz sederhana dan mencobanya di smartphone android miliknya. 


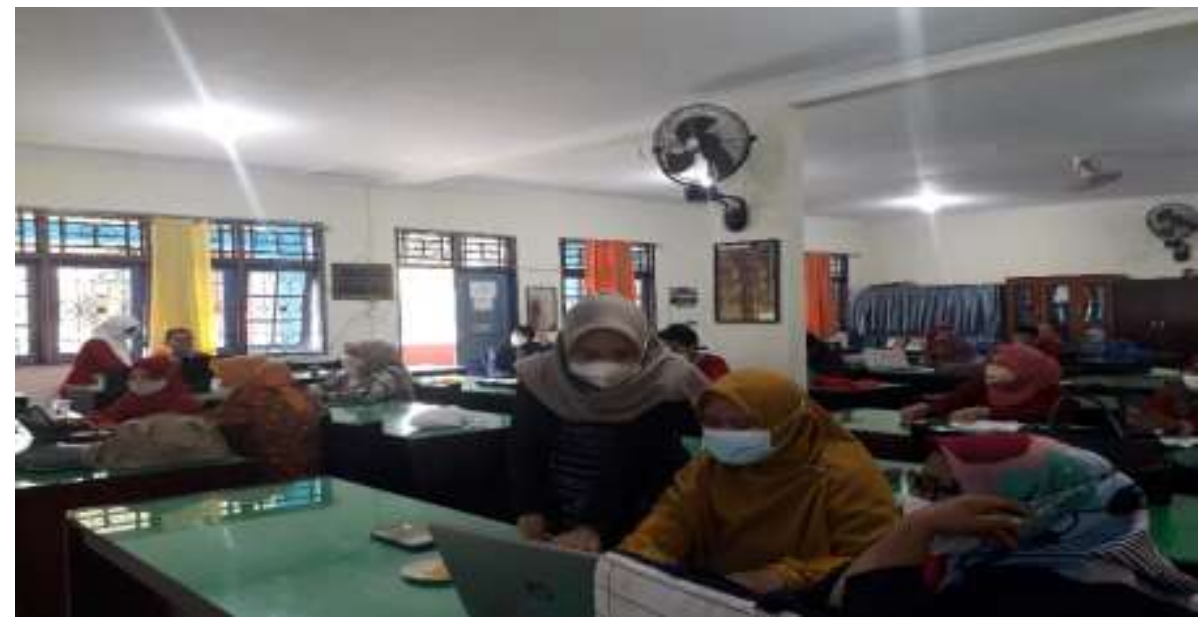

Gambar 2. Sesi Pendampingan Pembuatan Game

Peserta dan tim pengabdian istirahat, sholat, dan makan mulai dari 12.15 - 13.30 WITA. Pukul 13.30 WITA, pemateri melanjutkan pemaparan materi terakhir yakni membuat game edukasi berbasis android dengan quickappninja.com. Pemateri kelima (Muhammad Erfan, S.Pd., M.Pd.) menjelaskan bagaimana membuat games edukasi sederhana dengan quickappninja.com. Pemateri memberikan arahan bahwa guru membutuhkan sumber gambar dan pertanyaan yang diperlukan untuk quiz yang akan dibuat. Minimal pertanyaan yang harus dibuat adalah sebanyak 50 butir. Setelah proses input pertanyaan dan gambar selesai, dengan prosedur yang sama (appsgeyser.com), aplikasi dapat didownload dan diinstal di smartphone berbasis android. Pukul 14.30 WITA kegiatan pemberian materi sekaligus diskusi dikahiri. Pukul 14.30 - 14.45 WITA dilaksanakan penutupan dan foto bersama. Kegiatan berakhir pada 14.45 WITA.

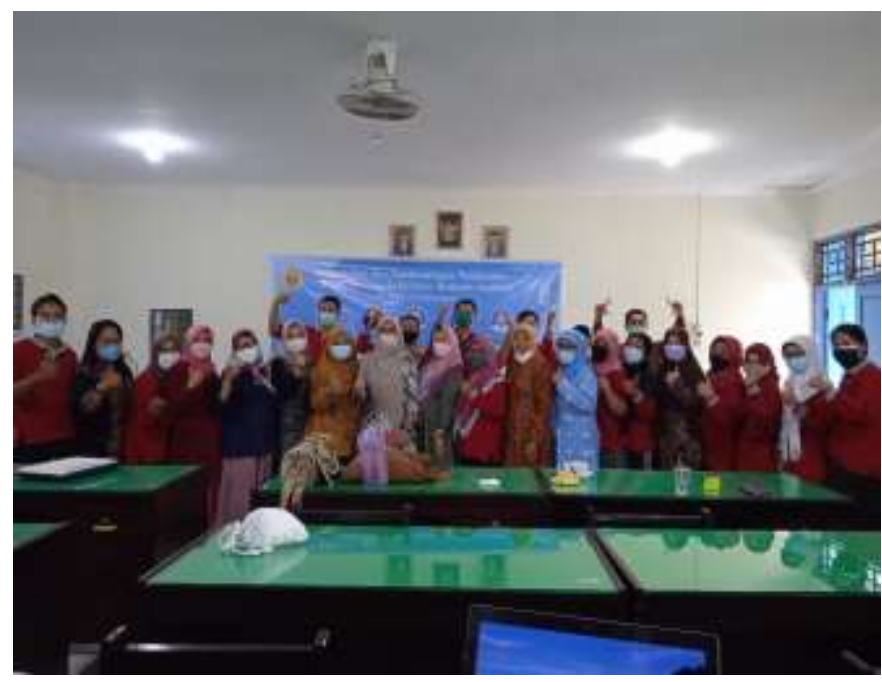

Gambar 3. Sesi Penutupan dan Foto Bersama

Berdasarkan observasi dan wawancara secara klasikal terhadap guru-guru SDN 2 Cakranegara selama proses pengabdian berlangsung, didapatkan hasil sebagai berikut.

1. Guru sudah melaksanakan pembelajaran daring dengan berbagai inovasi platform dan media pembelajaran interaktif yang diketahuinya. Sebagian besar guru belum pernah mengembangkan permainan edukasi yang bisa dimanfaatkan dalam kegiatan pembelajaran.

2. Sebagian besar guru memiliki ide-ide kreatif yang ingin dituangkan menjadi kuis yang bisa dengan interaktif diakses siswa dalam pembelajaran. Meskipun begitu, guru masih belum bisa mengeksekusi ide-ide tersebut dalam bentuk games atau permainan yang menarik dan mudah diakses oleh siswa selama pembelajaran di masa pandemic. 
3. Guru-guru menyadari bahwa banyak pembelajaran, bahkan quiz yang dapat dikemas secara menarik dalam bentuk permainan yang dapat diakses oleh siswa dengan mudah.

4. Guru-guru menyadari bahwa untuk membuat permainan berbasis android, tidak diperlukan coding yang sulit. Kita hanya perlu mendesain quiz atau permainan dengan menu-menu yang tersedia di website. Guru perlu mempersiapkan gambar, ikon, music, dan beberapa hal yang diperlukan dalam kuis yang akan dikemas ke dalam bentuk permainan. Setelah seluruhnya siap, guru bisa membuat game yang diinginkan.

Guru merasa sangat termotivasi untuk mengembangkan bentuk permainan melalui website yang tersedia (appsgeyser.com dan quickappninja.com). Konversi aplikasi permainan sehingga bisa diinstal dan diakses melalui smartphone android juga dilakukan dengan sangat mudah. Guru-guru menjadi lebih terbantu agar siswa dapat lebih focus dan tertarik pada materi pembelajaran di sekolah.

\section{KESIMPULAN}

Kegiatan Workshop dan Pendampingan Pembuatan Game Edukasi Berbasis Android bagi Guru-guru SDN 2 Cakranegara telah terlaksana dengan lancar. Kegiatan dilaksanakan secara tatap muka dengan tetap mematuhi protocol Kesehatan. Kepala sekolah dan guru-guru di SDN 2 Cakranegara menyambut dengan baik kegiatan pengabdian ini. Seluruh peserta workshop dan pendampingan mendapatkan materi mengenai pembuatan game edukasi berbasis android. Guruguru memiliki keterampilan dan ide-ide yang ingin nantinya dicurahkan dalam aplikasi game yang akan dibuat dan dapat diakses oleh siswa SD. Guru mendapatkan keterampilan dalam merancang dan memproduksi games dengan mudah tanpa kemampuan coding. Guru juga bisa melakukan instalasi pada smartphone android dan memainkannya sehingga diperoleh gambaran bagaimana nantinya games ini diakses oleh peserta didik.

\section{UCAPAN TERIMA KASIH}

Ucapan terimakasih diberikan pada DIPA BLU FKIP Universitas Mataram Tahun 2021 yang mendanai program workshop dan pendampingan ini.

\section{DAFTAR PUSTAKA}

Ariona, R. (2014). Game Edukasi Pengenalan Warna Sebagai Media- Pembelajaran Anak Usia Prasekolah Berbasis Android. Jurnal Teknik Elektro, 6(1), 30. https://doi.org/10.15294/JTE.V6I1.3573

Ayenigbara, I. (2018). Gaming Disorder and Effects of Gaming on Health: An Overview. Journal of Addiction Medicine and Therapeutic Science, 4, 001-003. https://doi.org/10.17352/24553484.000025

Blanco-Herrera, J. A., Gentile, D. A., \& Rokkum, J. N. (2019). Video Games can Increase Creativity, but with Caveats. Creativity Research Journal, 31(2), 119-131. https://doi.org/10.1080/10400419.2019.1594524

Dewantara, D., Wati, M., Misbah, M., Mahtari, S., \& Haryandi, S. (2020). The Effectiveness of Game Based Learning on The Logic Gate Topics. Journal of Physics: Conference Series, 1491(1), 012045. https://doi.org/10.1088/1742-6596/1491/1/012045

Dewi, R. M., Sholikhah, N., Ghofur, M. A., \& Soejoto, A. (2020). Pelatihan Game Edukasi Android Berbasis HOTS Sebagai Media Evaluasi Pembelajaran. Abimanyu: Journal of Community Engagement, 1(1), 59-67. https://doi.org/10.26740/ABI.V1I1.6791 
Dewi, W. A. F. (2020). Dampak COVID-19 terhadap Implementasi Pembelajaran Daring di Sekolah Dasar. Edukatif: Jurnal Ilmu Pendidikan, 2(1), 55-61. https://doi.org/10.31004/EDUKATIF.V2I1.89

Granic, I., Lobel, A., \& Engels, R. C. M. E. (2014). The benefits of playing video games. American Psychologist, 69(1), 66-78. https://doi.org/10.1037/a0034857

Grüsser, S. M., Thalemann, R., \& Griffiths, M. D. (2007). Excessive Computer Game Playing: Evidence for Addiction and Aggression? CyberPsychology \& Behavior, 10(2), 290-292. https://doi.org/10.1089/cpb.2006.9956

P, C.-L., \& D, B. (2014). Video game play, attention, and learning: how to shape the development of attention and influence learning? Current Opinion in Neurology, 27(2), 185-191. https://doi.org/10.1097/WCO.0000000000000077

Quwaider, M., Alabed, A., \& Duwairi, R. (2019). The Impact of Video Games on the Players Behaviors: A Survey. Procedia Computer Science, 151, 575-582. https://doi.org/10.1016/j.procs.2019.04.077 